\title{
Analisis dan Perancangan Sistem Informasi Geografis Universitas Negeri Manado Berbasis Web
}

\author{
Ferdinan Ivan Sangkop ${ }^{1}$ \\ Universitas Negeri Manado \\ e-mail: ivan.sangkop@unima.ac.id \\ Trudi Komansilan ${ }^{2}$ \\ Universitas Negeri Manado \\ e-mail: trudikomansilan@unima.ac.id
}

\begin{abstract}
ABSTRAK
Universitas Negeri Manado sebagai salah satu perguruan tinggi Negeri di Sulawesi Utara, terletak di daerah pegunungan Kabupaten Minahasa dengan luas lahan 270 hektar terdiri dari berbagai fakultas, program studi, dan fasilitas lainnya yang tersebar di berbagai lokasi. Tidak tersedianya peta sebagai denah lokasi bangunan dan fasilitas di universitas menyulitkan banyak pengunjung dan civitas akademika dalam mencari suatu lokasi. Dibutuhkan sistem informasi geografis yang dapat memberikan informasi geografis Universitas Negeri Manado dengan menggunakan peta sebagai delivery channel alternatif dengan tampilan dan interaksi yang lebih menarik. Model pengembangan yang digunakan adalah model sekuensial linier dengan pengusulan pada pendekatan proses yang sistematik dan sekuensial. Pada penelitian ini akan dibuat analisa dan perancangan sistem informasi geografis Universitas Negeri Manado berbasis web, dengan menggunakan Qgis dan HTML.
\end{abstract}

Kata kunci: Peta, Sistem Informasi Geografis, Denah Lokasi Universitas Negeri Manado

\begin{abstract}
Universitas Negeri Manado as one of the state universities in North Sulawesi, is located in the mountain area of Minahasa Regency with an area of 270 hectares consisting of various faculties, study programs and other facilities spread across various locations. The unavailability of maps consist the buildings and facilities location at the university makes it difficult for many visitors and academics to find a location. Geographical information systems are needed that can provide geographic information of Universitas Negeri Manado by using maps as alternative delivery channels with better user interface and interactive web pages. The development model used is linear sequential model that emphasis for a systematic and sequential process approach. In this study, an analysis and design of web-based geographic information systems will be made, using Qgis and HTML.
\end{abstract}

Keywords: Map, Geographic Information System, Universitas Negeri Manado Location Blueprint

\section{PENDAHULUAN}

Dewasa ini perkembangan teknologi di dunia semakin pesat, khususnya kemajuan di bidang teknologi informasi telah merambah berbagai bidang termasuk pendidikan. Universitas Negeri Manado sebagai salah satu perguruan tinggi Negeri di Manado, terletak di daerah pegunungan Kabupaten Minahasa dengan luas lahan 270 hektar terdiri dari berbagai fakultas, program studi, dan fasilitas lainnya yang tersebar di berbagai lokasi. Salah satu media informasi yang dapat digunakan untuk menampilkan profil Universitas Negeri Manado dengan segala kelebihan dan fasilitasnya adalah dengan menggunakan sistem informasi. Dibutuhkan sistem informasi geografis yang dapat memberikan informasi geografis Universitas Negeri Manado dengan menggunakan peta sebagai delivery channel alternatif dengan tampilan dan interaksi yang lebih menarik. Sistem Informasi Geografis merupakan sistem 
informasi berbasis komputer yang digunakan untuk mengolah dan menyimpan data atau informasi geografis (Prahasta, 2005). Pada penelitian ini akan dibuat analisa dan perancangan aplikasi pemetaan wilayah Universitas Negeri Manado berbasis web, dengan aplikasi Quantum Gis (Qgis) untuk pemetaannya, dibangun dengan bahasa pemrograman HTML untuk desain tampilan situs serta menggunakan dBASE sebagai DBMS untuk data-data yang terkait dengan Fakultas, Program Studi dan fasilitas yang terdapat di Universitas Negeri Manado. Web mapping digunakan untuk menampilkan peta dengan kemampuan interaksi sederhana, seperti perbesaran, perkecilan dan pergeseran gambar (Aziz dan Pujiono, 2006).

Tujuan penelitian yang ingin dicapai adalah untuk menganalisa dan merancang Sistem Informasi Geografis Universitas Negeri Manado berbasis web yang interaktif dan user friendly. Serta, memberikan informasi geografis penyebaran Fakultas, Program Studi, dan fasilitas lainnya di Universitas Negeri Manado.

\section{METODE}

Model pengembangan yang digunakan dalam penelitian ini adalah model sekuensial linier yang sering disebut juga dengan waterfall model dan merupakan paradigma rekayasa perangkat lunak yang mengusulkan pada pendekatan proses yang sistematik dan sekuensial yang dimulai pada tingkat dan kemajuan sistem pada seluruh analisis, desain, implementasi, dan pengujian (Roger S Pressman,2010). Pada waterfall model proses terbagi menjadi tahapan-tahapan yang mengikuti pola yang teratur dan dilakukan secara topdown, seperti layaknya air terjun.

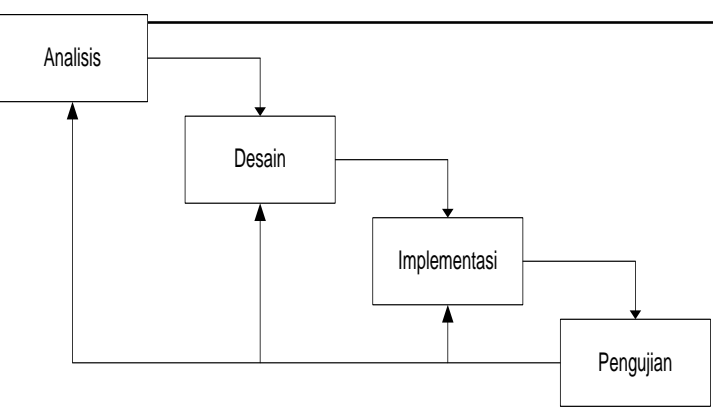

Gambar 1. Model Sekuensial Linier

\section{HASIL DAN PEMBAHASAN}

Analisis kebutuhan fungsional akan menjabarkan proses dan aliran data di dalam sistem, proses diawali dengan User melakukan login kemudian akan menampilkan peta penyebaran fakultas dan program studi Universitas Negeri Manado. User dapat memilih untuk menampilkan data yang diinginkan. Inputan data yang dimasukkan berupa data fakultas dan program studi yang akan disimpan dalam database.

Beberapa fungsi produk perangkat lunak sistem informasi geografis adalah sebagai berikut :

a. Fungsi Display Peta adalah fungsi yang digunakan untuk menampilkan peta penyebaran fakultas, program studi, fasilitas dan lembaga di Universitas Negeri Manado.

b. Fungsi Display Informasi adalah fungsi yang digunakan untuk menampilkan informasi lengkap dari suatu lokasi yang diinginkan.

c. Fungsi Display Home adalah fungsi yang digunakan untuk menampilkan halaman utama. 


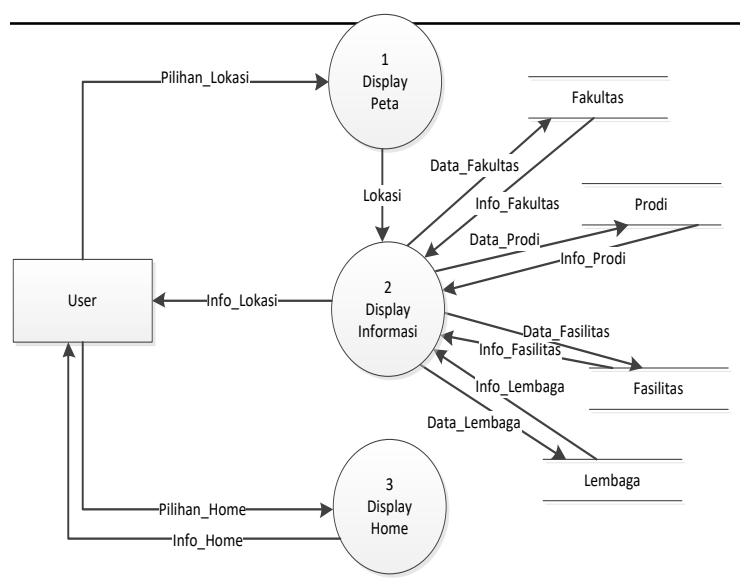

Gambar 2. Diagram Aliran Data

Terdapat 4 tabel yang tersimpan pada basis data dan telah menjadi entitas dasar antara lain Fakultas, Prodi, Fasilitas dan Lembaga. Dengan menghubungkan relasi yang menunjukkan keterkaitan antara satu entitas dengan entitas yang lainnya maka dapat diketahui derajat hubungan yang ada dari masing-masing entitas.

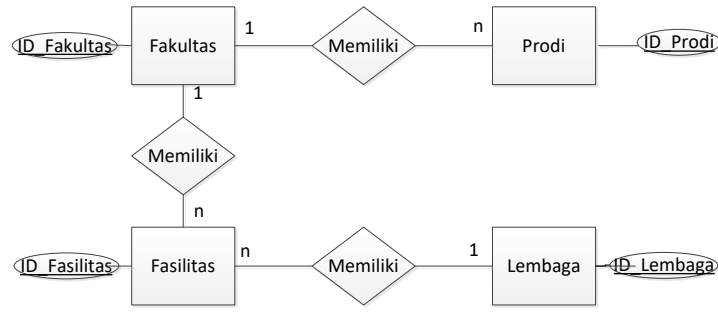

Gambar 3. Entity Relationship Diagram

Dalam pembuatan sebuah sistem aplikasi hal yang perlu di perhatikan adalah desain interface program yang merupakan perantara antara sistem dengan pengguna. Antarmuka halaman utama yang akan ditampilkan pertama kali saat dikunjungi oleh user. Pada halaman tersebut logo universitas dan label nama program serta pilihan link-link yang menghubungkan ke tertentu tertentu sesuai fungsinya masing-masing.

Jurnal Frontiers Vol 1 No 3, Desember 2018

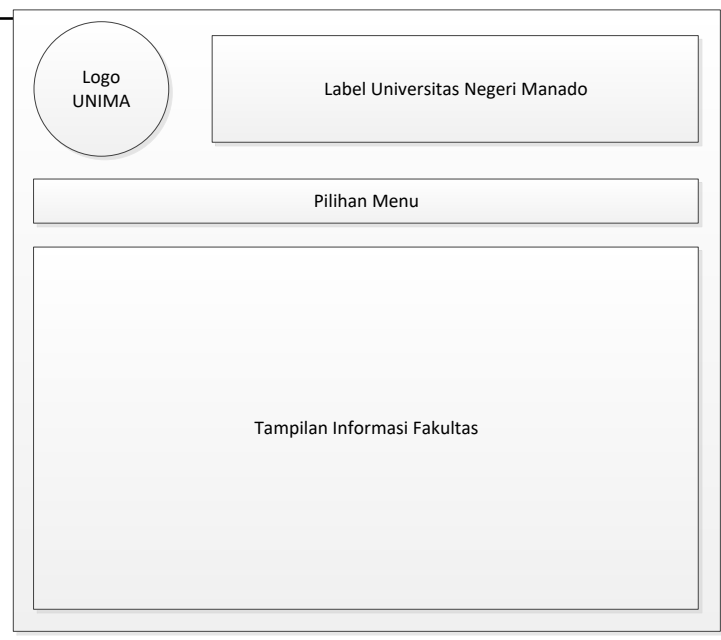

Gambar 4. Desain Halaman Utama

Antarmuka halaman peta merupakan halaman yang digunakan untuk menampilkan peta penyebaran lokasi fakultas, program studi, lembaga dan fasilitas lainnya di lingkungan Universitas Negeri Manado.

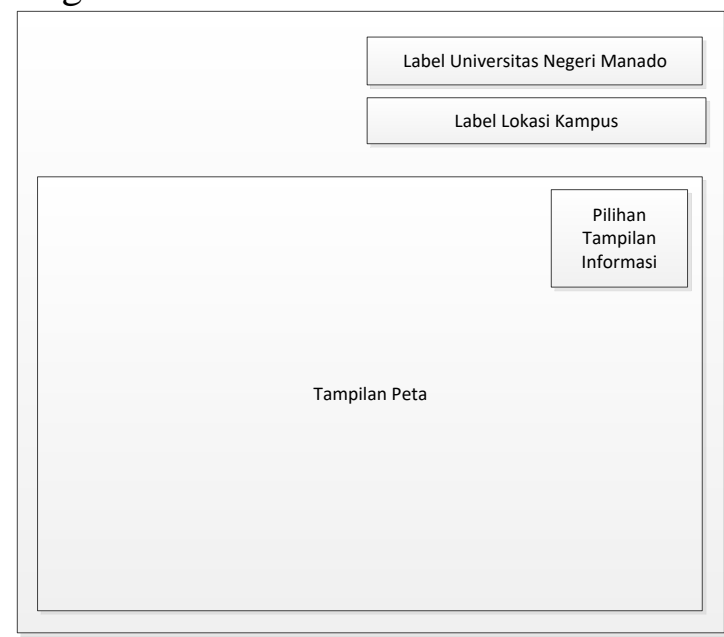

Gambar 5. Desain Halaman Tampilan Peta

Perangkat lunak sistem informasi geografis dikembangkan untuk menampilkan peta penyebaran fakultas, program studi dan fasilitas lainnya di Universitas Negeri Manado. Pengunjung berinteraksi dengan halaman sistem yang ditampilkan berbasis web. Implementasi antarmuka akan menuangkan desain 
antarmuka yang telah dibuat sebelumnya ke dalam bentuk graphical user interface (GUI) berbasis web page.

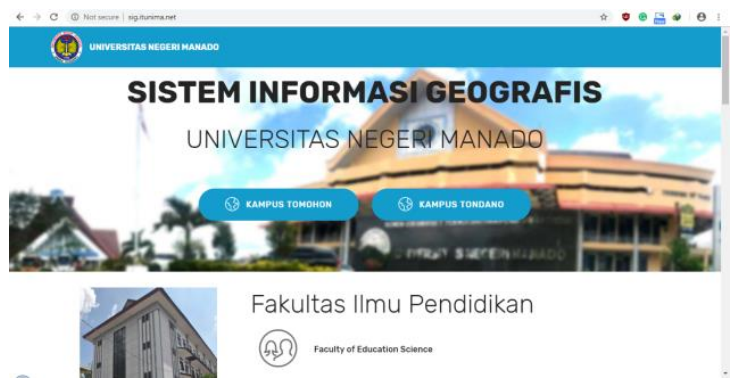

Gambar 6. Halaman Utama

Terdapat dua tombol link yang disediakan yaitu tombol Kampus Tomohon untuk membuka tampilan peta kampus UNIMA yang berada di Tomohon dan tombol Kampus Tondano untuk membuka tampilan peta kampus UNIMA yang berada di Tondano. Sementara itu halaman tampilan peta akan menampilkan peta penyebaran lokasi fakultas, program studi, lembaga dan fasilitas lainnya. Pada antarmuka ini akan menampilkan peta denah lokasi bangunan di Universitas Negeri Manado, kemudian pengguna dapat berinteraksi dengan peta tersebut dengan memilih lokasi tertentu yang diinginkan antara lain lokasi fakultas, program studi, lembaga, ataupun fasilitas lainnya seperti lapangan olahraga, bank, kantin serta perpustakaan.

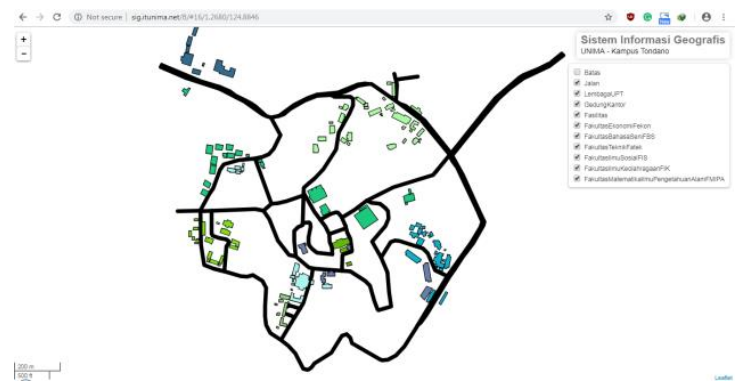

Gambar 7. Halaman Tampilan Peta
Masing-masing lokasi yang disediakan pada peta memiliki format penyimpanan masing-masing pada shapefile Arc View dalam bentuk line, polygon, dan point. Pengguna juga dapat melakukan penyaringan data dengan hanya memilih kategori tertentu dari lokasi yang mereka inginkan.

\section{PENUTUP}

\section{Kesimpulan}

Berdasarkan analisa dan rancangan sistem yang telah dihasilkan, dapat ditarik beberapa kesimpulan, yaitu Sistem Informasi Geografis Universitas Negeri Manado sebagai delivery channel alternatif dengan menggunakan peta dapat memberikan informasi penyebaran lokasi fakultas, program studi, lembaga dan fasilitas lainnya. Serta, implementasi aplikasi sangat penting untuk menunjang pelayanan dan kemudahan mengakses informasi lokasi Universitas Negeri Manado.

\section{Saran}

Saran bagi pengembanga program yang selanjutnya adalah bahwa pemetaan yang dilakukan dapat dikembangkan sehingga mampu menampilkan informasi geografis yang lebih luas mencakup Tondano dan daerah sekitarnya. Selain itu, tindak lanjut dalam bentuk pengembangan program berbasis mobile dapat dilaksanakan untuk mendukung penyebaran informasi.

\section{DAFTAR PUSTAKA}

Aziz, Muhammad, dan Pujiono, Slamet. (2006). Sistem Informasi Geografis Berbasis Desktop dan Web, Gava Media, Yogyakarta.

Prahasta, Eddy. (2005). Sistem Informasi Geografis : Konsep-konsep Dasar, Informatika, Bandung. 
Pressman, Roger S. (2010). Software

Engineering (a practitioner's
approach) $7^{\text {th }}$ edition. New York : McGraw-Hill, 2010.

\section{RIWAYAT HIDUP PENULIS}

Ferdinan Ivan Sangkop, ST., MT. Lahir di Ternate, 2 Februari 1985. Staf pengajar di Program Studi Teknik Informatika, Universitas Negeri Manado. Studi S1 Teknik Informatika di Universitas Atma Jaya Yogyakarta, lulus tahun 2007 dan S2 Magister Teknik Informatika di Universitas Atma Jaya Yogyakarta, lulus tahun 2009. 
